\title{
Interaction of $\mathrm{Cu}$ (II) with Cytosine in Britton-Robinson Buffer Solution - A Cyclic Voltammetric Study
}

\author{
A. A. Shaikh*, Jannatul Firdaws, S. Islam and P. K. Bakshi \\ Department of Chemistry, Dhaka University, Dhaka-1000, Bangladesh
}

(Received : 16 April 2014; Accepted : 10 August 2014)

\begin{abstract}
Electrochemical redox behavior of $\mathrm{Cu}$ (II) at different $\mathrm{pH}$ in Britton-Robinson (BR) buffer solution has been investigated using cyclic voltammetry at glassy carbon electrode (GCE). $\mathrm{Cu}(\mathrm{II})$ shows a cathodic peak and a hump-like peak, and an intense anodic peak at $\mathrm{pH}, 0.59$, $1.59,3.01$ and 4.08. Although at lower $\mathrm{pH}(0.59$ and 1.59) a cathodic peak, a hump and an anodic peak are observed, at higher pH (3.01 and 4.08 ) the hump-like cathodic peak disappeared. Cyclic voltammetry has also been used to observe the interaction of $\mathrm{Cu}(\mathrm{II}) \mathrm{with}$ cytosine in $\mathrm{BR}$ buffer solution at various $\mathrm{pH}$. A reasonably strong interaction between $\mathrm{Cu}(\mathrm{II})$ and cytosine at different $\mathrm{Cu}$ (II)/cytosine molar ratio is observed at all the studied $\mathrm{pH}$. However, maximum interaction occurs at 1:4 molar ratio at $\mathrm{pH} 4.08$, this is perhaps the most suitable condition for $\mathrm{Cu}(\mathrm{II})$-cytosine interaction.
\end{abstract}

Keywords: Cytosine; Britton-Robinson buffer; Glassy carbon electrode; Peak potential

\section{Introduction}

Cytosine is one of the five main nitrogenous bases used in storing and transporting genetic information within a cell ${ }^{1}$. It is a pyrimidine derivative, with a heterocyclic aromatic ring and two substituent attached (an amine group at position 4 and a keto group at position 2). The nucleoside of cytosine is cytidine ${ }^{2}$. DNA methylation involves the addition of a methyl group to the 5 position of the cytosine pyrimidine ring or the number 6 nitrogen of the adenine purine ring (cytosine and adenine are two of the four bases of DNA). DNA methylation also plays a crucial role in the development of nearly all types of cancer $^{3}$. DNA methylation involves the addition of a methyl group to DNA, for example, to the number 5 carbon of the cytosine pyrimidine ring, in this case with the specific effect of reducing gene expression. DNA methylation at the 5 position of cytosine has been found in every vertebrate examined. Cytosine plays a vital role in pairing, through hydrogen bonds with the guanine base of guanosine and deoxyguanosine. Cytosine is involved in the genetic codon of 17 amino acids and controls the essential features of life ${ }^{4}$.

Although cytosine is a base it can act as a ligand because of the presence of unpaired electrons on nitrogen and oxygen which are available to donate in complexation reaction. Cyclic voltammetric behaviour of cytosinato bridged complexes of ruthenium(II) and platinum(II) with 1-alkyl-2(arylazo)imidazoles were investigated ${ }^{5}$. Electrochemical properties of the complexes have been examined by cyclic voltammetry in $\mathrm{CH}_{3} \mathrm{CN}$ in presence of $\left[\mathrm{n}-\mathrm{Bu}_{4} \mathrm{~N}\right]\left[\mathrm{ClO}_{4}\right]$ as supporting electrolyte using a Pt-disc working electrode at the scan rate of $50 \mathrm{mV} / \mathrm{s}$. Although several groups ${ }^{6-8}$ have tried to investigate the electrochemical interaction of metalcytosine with different electrodes, our aim is to investigate the interaction of $\mathrm{Cu}$ (II) with cytosine in BR buffer medium maintaining various $\mathrm{pH}$ at GCE using cyclic voltammetry.

\section{Experimental}

\section{Materials}

Analar grade $\mathrm{Cu}\left(\mathrm{NO}_{3}\right)_{2} \cdot 3 \mathrm{H}_{2} \mathrm{O}$ was purchased from Merck, Germany and used without further purification. Analytical grade cytosine (BDH, UK) was used in this study. Acetic acid (BDH, UK), phosphoric acid (Merck, Germany), and boric acid (Merck, Germany) were also used for the preparation of BR buffer. Sodium hydroxide (Merck, Germany) and perchloric acid (BDH, UK) were used as it is available for maintaining the $\mathrm{pH}$ of the solution. All aqueous solutions were prepared in doubly distilled water obtained from a Milli-Q water purification system. The experiments were carried out at room temperature.

\section{Equipments}

Three electrodes system consisting of a GCE as the working electrode, $\mathrm{Ag} / \mathrm{AgCl}$ (satd. $\mathrm{KCl}$ ) as the reference electrode and a platinum wire as the counter electrode was used. Cyclic voltammetric measurement was performed using Computerized Electrochemical System, Model HQ-2040 developed by Advanced Analytics, USA. Solution $\mathrm{pH}$ was measured with a $\mathrm{pH}$ meter (Microprocessor $\mathrm{pH}$ meter, model pH 211, HANNA Instruments).

\section{Methods}

\section{Preparation of Britton-Robinson buffer solution}

For the preparation of $\mathrm{BR}$ buffer solution, $0.04 \mathrm{M} \mathrm{H}_{3} \mathrm{BO}_{3}$, $0.04 \mathrm{M} \mathrm{H}_{3} \mathrm{PO}_{4}$ and $0.04 \mathrm{M} \mathrm{CH} \mathrm{CH}_{3} \mathrm{COOH}$ solutions were prepared separately, and the three solutions were then mixed together with same volume ratio. By adding $0.2 \mathrm{M} \mathrm{NaOH}$ or $\mathrm{HClO}_{4}$ solution the desired $\mathrm{pH}$ values $(\mathrm{pH}$ values are 0.59 , $1.59,3.01$ and 4.08) were adjusted.

\section{Preparation of metal ion and cytosine solution}

Metal ion solution of $0.5 \mathrm{mM} \mathrm{Cu}$ (II) was prepared using BR buffer. For the complexation study, 0.5, 1.0, 1.5 and $2.0 \mathrm{mM}$ cytosine solutions were also prepared using BR buffer solution.

\footnotetext{
*Author for Correspondence.e-mail: aftabshaikh@univdhaka.edu
} 


\section{Preparation of working electrode}

GCE was polished with fine alumina powder of 0.3 micron on a wet polishing cloth. For doing so a part of the cloth was made wet with deionized water, and alumina powder was sprinkled over it. The GCE was then polished on this surface by pressing softly the electrode against the polishing surface for about 10 minutes. A shiny black mirror like electrode surface was then thoroughly washed with deionized water.

First of all, the cell was filled with desired volume of the experimental solution and the Teflon cap was placed on the cell. The purging glass tube together with reference electrode was inserted through the holes. Under computer controlled stirring, experimental solution was deaerated by purging for at least 10 minutes with $99.9977 \%$ pure nitrogen gas. Thus traces of dissolved oxygen were removed from the solution.

\section{Results and Discussion}

Cyclic voltammetric investigation of the redox behavior of $\mathrm{Cu}(\mathrm{II})$ in BR buffer solution, and its interaction with cytosine in an identical voltammetric condition has been performed. The effect of $\mathrm{pH}$ for this study was also examined. The results are presented below:

\section{Voltammetric response of Cu(II) in BR buffer solution}

Cyclic voltammetric study of $0.5 \mathrm{mM} \mathrm{Cu}$ (II) in BR buffer at different $\mathrm{pH}$ values ( 0.59 to 4.08$)$ has been investigated at GCE within the potential window of 500 to $-500 \mathrm{mV}$. At more positive or negative potential values only non-faradic current is observed. Figure 1(a) shows a cyclic voltammogram of $0.5 \mathrm{mM} \mathrm{Cu}$ (II) in BR buffer solution with scan rate of $100 \mathrm{mVs}^{-1}$ at $\mathrm{pH} 1.59$. In the forward scan two cathodic peaks $i_{p c l}$ (a hump like peak) and $i_{p c 2}$ at about 9.84 $\mathrm{mV}$ and $\quad-84.96 \mathrm{mV}$ respectively, and in the reverse scan an intense anodic peak $i_{p a 2}$ at about $67.60 \mathrm{mV}$ are observed. The cathodic peaks are due to the reduction of $\mathrm{Cu}$ (II) to $\mathrm{Cu}(\mathrm{I})$ and $\mathrm{Cu}(\mathrm{I})$ to $\mathrm{Cu}(0)$, while the intense anodic peak is for the oxidation of $\mathrm{Cu}(0)$ to $\mathrm{Cu}(\mathrm{II})$. However, cyclic voltammogram of cytosine in an identical experimental condition shows no peak (Figure 1(b)).

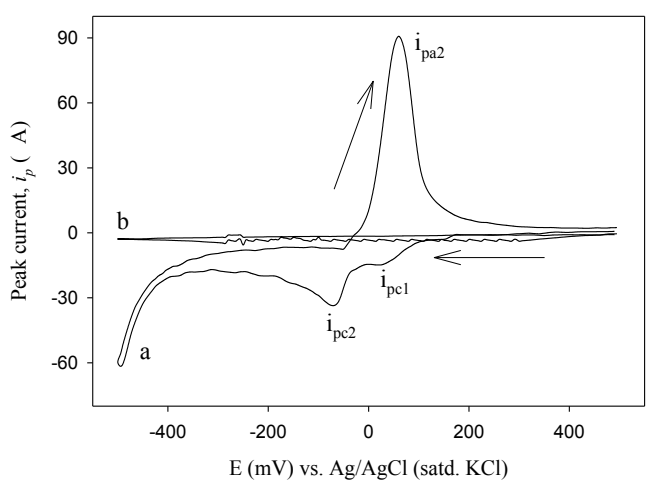

Fig. 1. Cyclic voltammograms of (a) $0.5 \mathrm{mM} \mathrm{Cu}$ (II) and (b) 0.5 $\mathrm{mM}$ cytosine in Britton-Robinson buffer at $\mathrm{pH} 1.59$ with scan rate of $100 \mathrm{mVs}^{-1}$ at GCE.

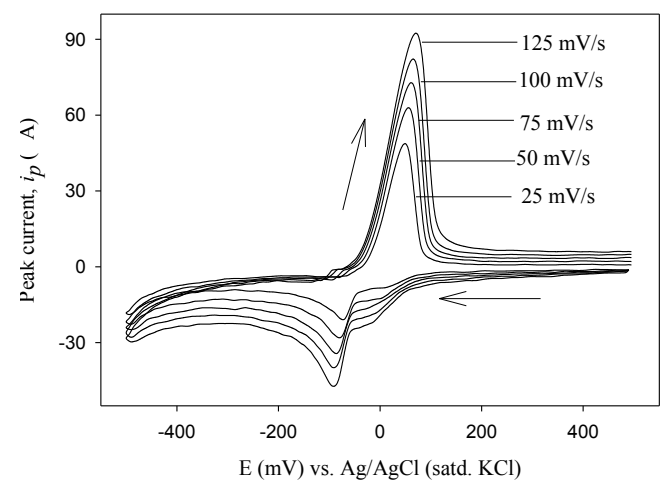

Fig. 2. Cyclic voltammograms of $0.5 \mathrm{mM} \mathrm{Cu}(\mathrm{II})$ in BrittonRobinson buffer solution with scan rate of $25,50,75,100$ and $125 \mathrm{mVs}^{-1}$ at $\mathrm{pH} 1.59$.

The effect of the scan rate on the electrochemical response of $\mathrm{Cu}(\mathrm{II})$ at $\mathrm{pH} 1.59$ is also examined by gaining the cyclic voltammograms of $\mathrm{Cu}(\mathrm{II})$ with scan rate of $25,50,75,100$ and $125 \mathrm{mVs}^{-1}$ under identical condition. The voltammograms are shown in Figure 2.

Table 1. Data obtained from the cyclic voltammograms of $0.5 \mathrm{mM} \mathrm{Cu}$ (II) in Britton-Robinson buffer with different scan rate at $\mathrm{pH} 1.59$.

\begin{tabular}{|c|c|c|c|c|c|c|c|c|}
\hline \multirow[t]{2}{*}{$\begin{array}{l}\text { Scan rate, } \\
v\left(\mathrm{mVs}^{-1}\right)\end{array}$} & \multicolumn{2}{|c|}{$\begin{array}{c}\text { Cathodic peak } \\
\text { current, } i_{p c} \\
\text { (A) }\end{array}$} & \multirow{2}{*}{$\begin{array}{c}\mathrm{APC}, i_{p a} \\
(\mathrm{~A}) \\
i_{p a 2}\end{array}$} & \multicolumn{2}{|c|}{$\begin{array}{c}\text { Cathodic peak } \\
\text { potential, } \mathrm{E}_{\mathrm{pc}} \\
(\mathrm{mV})\end{array}$} & \multirow{2}{*}{$\begin{array}{c}\mathrm{APP}, \mathrm{E}_{\mathrm{pa}} \\
(\mathrm{mV})\end{array}$} & \multirow[t]{2}{*}{$\begin{array}{c}\mathrm{PCR} \\
i_{p a 2} / i_{p c 2}\end{array}$} & \multirow[t]{2}{*}{$\begin{array}{c}\mathrm{E}_{\mathrm{p}}=\mathrm{E}_{\mathrm{pa} 2}-\mathrm{E}_{\mathrm{pc} 2} \\
(\mathrm{mV})\end{array}$} \\
\hline & $\begin{array}{l}i_{p c l} \\
(-)\end{array}$ & $\begin{array}{l}i_{p c 2} \\
(-)\end{array}$ & & $\mathrm{E}_{\mathrm{pc} 1}$ & $\begin{array}{c}E_{p c 2} \\
(-)\end{array}$ & & & \\
\hline 25 & 13.25 & 20.96 & 48.57 & 9.84 & 79.88 & 50.00 & 2.31 & 130 \\
\hline 50 & 8.57 & 27.87 & 63.33 & 5.04 & 82.32 & 57.60 & 2.27 & 140 \\
\hline 75 & 12.16 & 28.24 & 73.30 & 7.86 & 82.32 & 58.40 & 2.59 & 140 \\
\hline 100 & 13.94 & 34.65 & 82.85 & 9.84 & 84.96 & 67.60 & 2.39 & 152 \\
\hline 125 & 20.07 & 47.75 & 92.41 & 2.40 & 92.40 & 72.00 & 2.01 & 164 \\
\hline
\end{tabular}

$\mathrm{APC}=$ Anodic peak current, $\mathrm{APP}=$ Anodic peak potential, $\mathrm{PCR}=$ Peak current ratio

The recorded voltammograms are analyzed and various parameters such as anodic and cathodic peak current, peak potential separation and peak current ratio are gathered as shown in Table 1. It is found that with the increase of scan rate, both the cathodic and anodic peak currents are increased (Figure 2). This observation suggests that the electrode process is under diffusion controlled in BR buffer medium. The anodic $\left(\mathrm{E}_{\mathrm{pa} 2}\right)$ and cathodic $\left(\mathrm{E}_{\mathrm{pc} 2}\right)$ peak potential separation $(130-164 \mathrm{mV})$ and anodic $\left(\mathrm{i}_{\mathrm{pa} 2}\right)$ and cathodic $\left(\mathrm{i}_{\mathrm{pc} 2}\right)$ peak current ratio (2.01-2.59) reveal that the redox process of copper system is quasi-reversible, in agreement with the observations on the shape of the cathodic and anodic peaks ${ }^{9}$. 
The cathodic peak is slightly shifted towards negative potential while the anodic peak is moved a little towards positive potential with the incease of scan rate. The shifting of the peak potential at various scan rates also indicates that the redox process is shifted from quasi-reversible to irreversible direction.

Figure 3 apparently shows that the peak current for the redox behavior of copper system in BR buffer bears a linear relationship with square root of scan rate and it passes through the origin. The ratio of the oxidation peak current to its corresponding reduction counterpart, $\mathrm{i}_{\mathrm{pa} 2} / \mathrm{i}_{\mathrm{pc} 2}$ is about 2.59-2.01. It is found (Figure 4) that the peak current ratio is decreased with the increase of scan rate. It is again in favor of the fact that the electrode process is diffusion-controlled. It is also in good agreement with the previous study ${ }^{10}$.

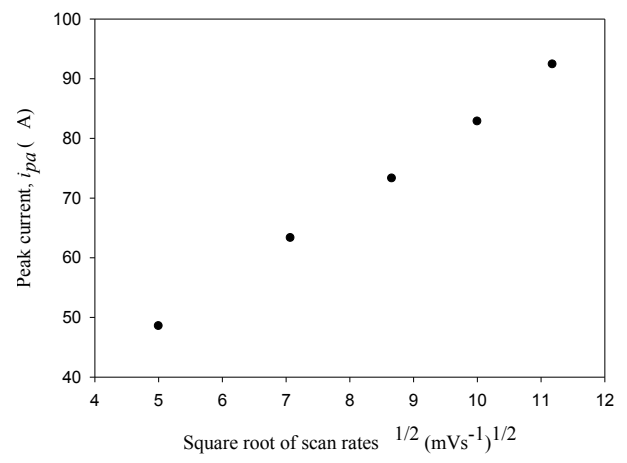

Fig. 3. Variation of peak current with square root of scan rate for $\mathrm{Cu}(\mathrm{II})$ in Britton-Robinson buffer at $\mathrm{pH}$ 1.59.

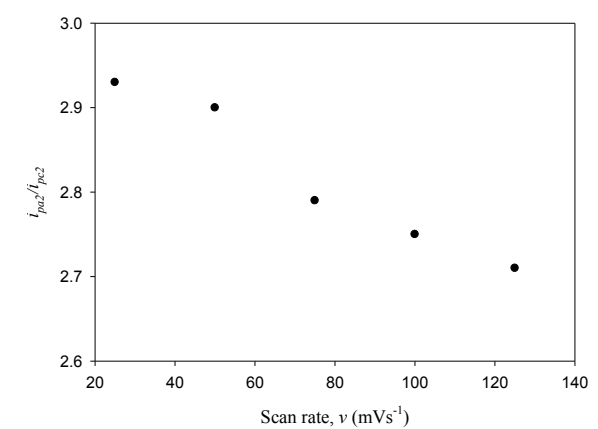

Fig. 4. Peak current ratio $\left(i_{p a 2} / i_{p c 2}\right)$ dependence on scan rate of 0.5 $\mathrm{mM} \mathrm{Cu}(\mathrm{II})$ in Britton-Robinson buffer medium at $\mathrm{pH} 1.59$.

The peak potential separation, $\mathrm{E}_{\mathrm{p}}$ is in between $130-164 \mathrm{mV}$ and it is increased with the increase of scan rate (Figure 5). It is evident that the redox process is quasi-reversible rather than a reversible.

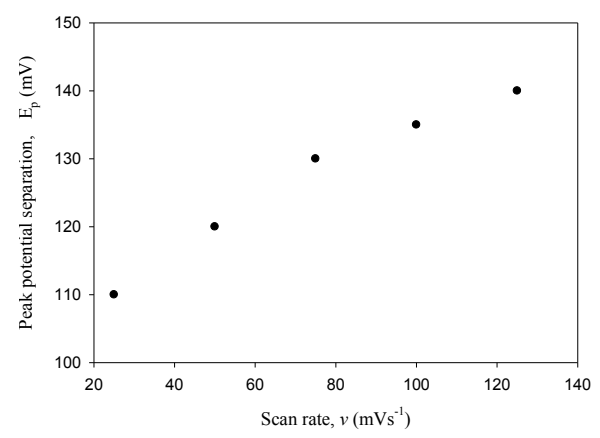

Fig. 5. Variation of peak potential separation with scan rate of 0.5 $\mathrm{mM} \mathrm{Cu}(\mathrm{II})$ in Britton- Robinson buffer at $\mathrm{pH}$ 1.59.

\section{Effect of $\mathrm{pH}$ on the redox behavior of $\mathrm{Cu}(\mathrm{II})$}

The effect of $\mathrm{pH}$ on redox behavior of $\mathrm{Cu}(\mathrm{II})$ in BR buffer has also been investigated at GCE. Voltammograms for $\mathrm{Cu}(\mathrm{II})$ in $\mathrm{BR}$ buffer at $\mathrm{pH} 0.59,1.59,3.01$ and 4.08 are recorded. A series of voltammograms at different $\mathrm{pH}$ of the solution are shown in Figure 6.

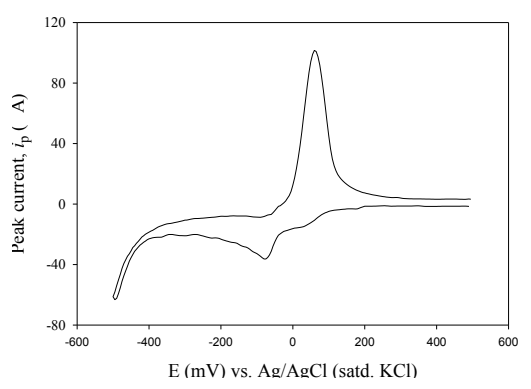

a

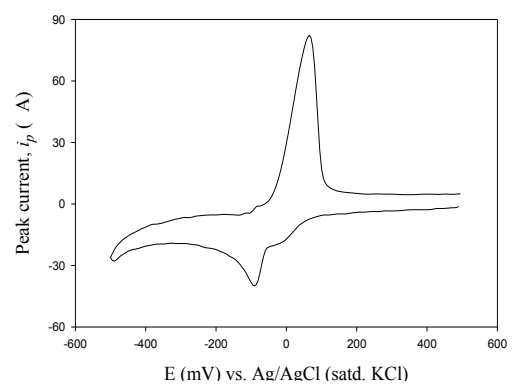

b

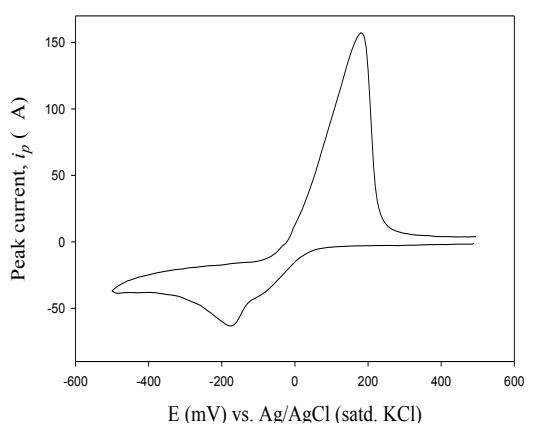

C

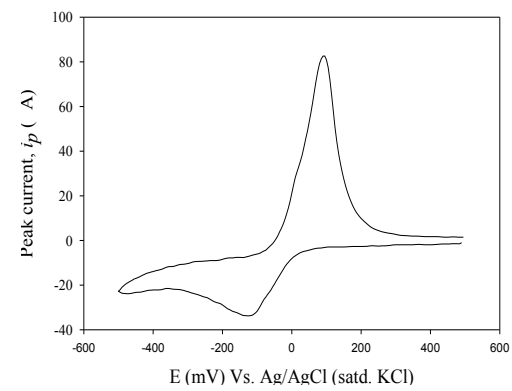

d

Fig. 6. Cyclic voltammograms of $0.5 \mathrm{mM} \mathrm{Cu}(\mathrm{II})$ in BrittonRobinson buffer at different $\mathrm{pH}$ : (a) 0.59 , (b) 1.59 , (c) 3.01 and (d) 4.08 at GCE. 
At low $\mathrm{pH}$ ranging from 0.59 to 3.08 , a cathodic peak and a hump-like peak, and an intense anodic peak are appeared. With the increase of $\mathrm{pH}$, the first cathodic peak current gradually decreases and finally disappears at $\mathrm{pH}$ 4.08. In general, both cathodic and anodic peak currents are decreased with the increase of $\mathrm{pH}$, as given in Table 2 . However, both the anodic and cathodic peaks are identical in shape and the peak potential separation is comparable. At low $\mathrm{pH}$ limit $\left[\mathrm{Cu}\left(\mathrm{H}_{2} \mathrm{O}\right)_{6}\right]^{2+}$ and $\left[\mathrm{Cu}\left(\mathrm{H}_{2} \mathrm{O}\right)_{6-\mathrm{x}}\right]^{+}$ions can be assumed to be present in significant amount while at high $\mathrm{pH}(\sim 4.08),\left[\mathrm{Cu}(\mathrm{OH})\left(\mathrm{H}_{2} \mathrm{O}\right)_{5}\right]^{+}$ion is understood to be the only electroactive species ${ }^{11,12}$. It has been mentioned before that $\mathrm{Cu}(\mathrm{I})$ as the solvated ion is stable in a number of nonaqueous solvents such as acetonitrile ${ }^{13}$, nitromethane ${ }^{12}$. In such solvents, the stability of $\mathrm{Cu}(\mathrm{I})$ is due to the fact that these solvents solvate $\mathrm{Cu}$ (II) less strongly than does water and they solvate $\mathrm{Cu}(\mathrm{I})$ more strongly than does water.

Table 2. Data obtained from the voltammogram of $\mathrm{Cu}(\mathrm{II})$ at different $\mathrm{pH}$.

\begin{tabular}{cccccc}
\hline \multirow{2}{*}{ Solution $\mathrm{pH}$} & \multicolumn{2}{c}{ Peak current, $i_{p}(\mathrm{~A})$} & Peak potential, $\mathrm{E}_{\mathrm{p}}(\mathrm{mV})$ & \multicolumn{2}{c}{$\begin{array}{c}\text { Peak potential } \\
\text { separation, } \mathrm{E}_{\mathrm{p}}\end{array}$} \\
\cline { 2 - 5 } & $i_{p c 2}(-)$ & $i_{p a 2}(+)$ & $\mathrm{E}_{\mathrm{pc} 2}(-)$ & $\mathrm{E}_{\mathrm{pa} 2}(+)$ & \\
\hline 0.59 & 35.94 & 100.97 & 80.16 & 54.96 & 134 \\
1.59 & 34.23 & 81.94 & 95.04 & 64.80 & 159 \\
3.01 & 62.45 & 155.53 & 180.00 & 179.76 & 359 \\
4.08 & 34.21 & 80.52 & 125.04 & 90.00 & 215 \\
\hline
\end{tabular}

Voltammetric response of $\mathrm{Cu}(\mathrm{II})$ in presence of cytosine in BR buffer solution

The voltammograms of $\mathrm{Cu}(\mathrm{II})$ in presence of cytosine in $\mathrm{BR}$ buffer at various $\mathrm{Cu}(\mathrm{II}) /$ cytosine molar ratio, 1:1, 1:2, 1:3 and 1:4 have been recorded at $\mathrm{pH} 0.59,1.59,3.01$ and 4.08 at GCE within the same potential window.

The recorded voltammograms of $\mathrm{Cu}(\mathrm{II})$, and at various $\mathrm{Cu}(\mathrm{II}) /$ cytosine molar ratio, $1: 1,1: 2,1: 3$ and $1: 4$ at $\mathrm{pH} 0.59$ is shown in Figure 7. At this $\mathrm{pH}$ the cathodic peak is significantly reduced and a large reduction of the anodic peak height is observed in the voltammograms and the peak currents are relatively lower than that of $\mathrm{Cu}(\mathrm{II})$ alone. Moreover, the heights of the peaks are apparently erratic with respect to cytosine concentration. The lowest peak current is found at 1:4 molar ratio of $\mathrm{Cu}(\mathrm{II})$ to cytosine concentration suggesting the maximum interaction occurs at this molar ratio. It is noted that the voltammogram of cytosine in identical condition exhibits no anodic or cathodic peak (Figure 1(b)) within the studied potential window.

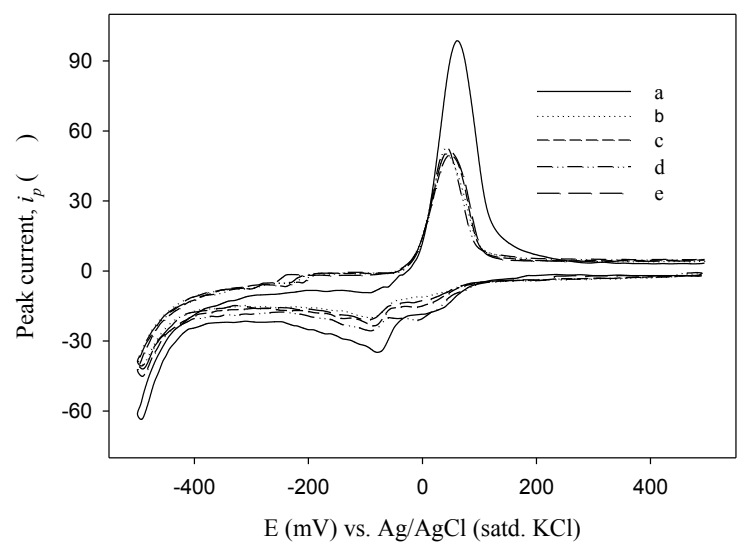

Fig. 7. Cyclic voltammograms of (a) $\mathrm{Cu}$ (II) (solid), and $\mathrm{Cu}(\mathrm{II})$ and cytosine with different molar ratio (b) 1:1 (dotted), (c) 1:2 (short dash), (d) 1:3 (dash-dot-dot) and (e) 1:4 (long dash) in Britton-Robinson buffer at $\mathrm{pH} 0.59$.

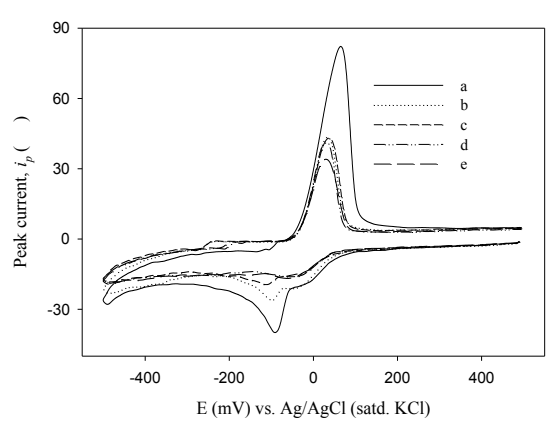

Fig. 8. Cyclic voltammograms of (a) $\mathrm{Cu}$ (II) (solid), and $\mathrm{Cu}$ (II) and cytosine with different molar ratio (b) 1:1 (dotted), (c) 1:2 (short dash), (d) 1:3 (dash-dot-dot) and (e) 1:4 (long dash) in Britton-Robinson buffer at $\mathrm{pH} 1.59$.

Figure 8 shows the voltammograms of $\mathrm{Cu}(\mathrm{II})$, and $\mathrm{Cu}$ (II) in presence of cytosine with different molar concentration at $\mathrm{pH}$ 1.59. A significant change of the shape of voltammograms is observed. The cathodic peak completely disappeared (at 1:3 and 1:4 molar ratio) while the anodic peak current considerably decreased compared to only $\mathrm{Cu}(\mathrm{II})$. The anodic peak potentials also shifted towards negative direction. Furthermore, the heights of the peaks are apparently inconsistent with respect to cytosine concentration. Since the lowest peak current (Table 3) is found for 1:4 molar ratio of $\mathrm{Cu}$ (II) to cytosine, the maximum interaction, is indeed, occurred at this molar ratio at $\mathrm{pH} 1.59$.

In presence of cytosine, $\mathrm{Cu}(\mathrm{II})$ displays almost identical electrochemical behavior at $\mathrm{pH} 3.01$ and 4.08. In most of the cases the cathodic peak disappears completely. The behaviors that are common in both cases, (i) significant decrease of the peak currents of $\mathrm{Cu}$ (II), (ii) slight shifting of peak potentials, (iii) inconsistent respond of peak current with respect to $\mathrm{Cu}(\mathrm{II}) /$ cytosine molar ratios, and (iii) a maximum interaction of $\mathrm{Cu}(\mathrm{II})$ with cytosine at their $1: 4$ molar ratio. The voltammograms recorded at $\mathrm{pH} 3.01$ and at 4.08 are shown in Figures 9 and 10 respectively. 


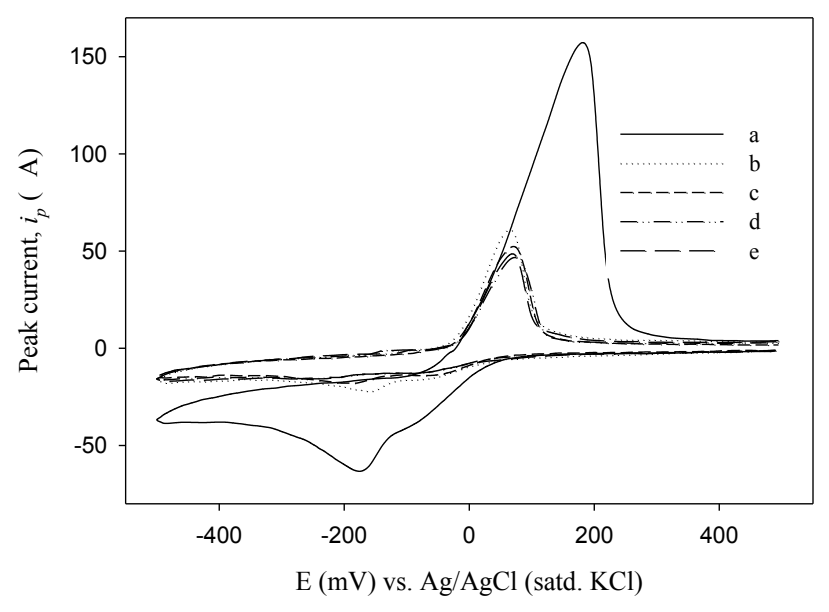

Fig. 9. Cyclic voltammograms of (a) $\mathrm{Cu}(\mathrm{II})$ (solid), and $\mathrm{Cu}(\mathrm{II})$ and cytosine with different molar ratio (b) 1:1 (dotted), (c) 1:2 (short dash), (d) 1:3 (dash-dot-dot) and (e) 1:4 (long dash) in Britton-Robinson buffer at $\mathrm{pH} 3.01$.

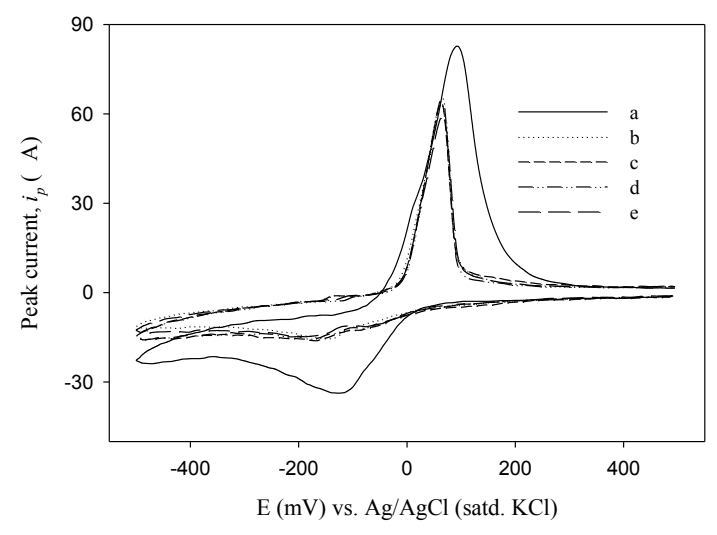

Fig. 10. Cyclic voltammograms of (a) $\mathrm{Cu}(\mathrm{II})$ (solid), and $\mathrm{Cu}(\mathrm{II})$ and cytosine with different molar ratio (b) 1:1 (dotted), (c) 1:2 (short dash), (d) 1:3 (dash-dot-dot) and (e) 1:4 (long dash) in Britton-Robinson buffer at $\mathrm{pH} 4.08$.

From the above observation it can be concluded that $\mathrm{Cu}(\mathrm{II})$ interacts strongly with cytosine at molar ratio of 1:4 at all studied $\mathrm{pH}$ in BR buffer medium. However, the maximum interaction occurs at $\mathrm{pH}$ 4.08. The data for the different voltammograms recorded for $\mathrm{Cu}(\mathrm{II}) /$ cytosine molar ratio of $1: 4$ at various $\mathrm{pH}$ is gathered in Table 3.

Table 3. The data for the voltammograms recorded for 1:4 molar ratio of $\mathrm{Cu}(\mathrm{II}) / \mathrm{cytosine}$ at different $\mathrm{pH}$ at $\mathrm{GCE}$ with scan rate of $100 \mathrm{mVs}^{-1}$.

\begin{tabular}{ccccccc}
\hline Solution $\mathrm{pH}$ & \multicolumn{2}{c}{ Peak current, $\mathrm{A}$} & \multicolumn{2}{c}{ Peak potential, $\mathrm{mV}$} & $\begin{array}{c}\text { Peak current } \\
\text { ratio }\left(\mathrm{i}_{\mathrm{pa}} / \mathrm{i}_{\mathrm{pc}}\right)\end{array}$ & $\begin{array}{c}\text { Peak potential } \\
\text { separation, }\end{array}$ \\
\cline { 2 - 7 } & $\mathrm{i}_{\mathrm{pc}}(-)$ & $\mathrm{i}_{\mathrm{pa}}(+)$ & $\mathrm{E}_{\mathrm{pc}}(-)$ & $\mathrm{E}_{\mathrm{pa}}(+)$ & & 136.00 \\
\hline 0.59 & 21.00 & 49.63 & 93.00 & 43.00 & 2.36 & 100.08 \\
1.59 & 16.15 & 34.16 & 70.08 & 30.00 & 2.11 & - \\
3.01 & - & 51.63 & - & 43.00 & - & - \\
4.08 & - & 51.00 & - & 63.00 & - & - \\
\hline
\end{tabular}

- indicates no significant value

\section{Conclusion}

Cyclic voltammogram of $\mathrm{Cu}(\mathrm{II})$ in BR buffer exhibits an intense cathodic peak and a hump-like peak, and a strong anodic peak at all studied $\mathrm{pH}$. However, at high $\mathrm{pH}$, only a cathodic and an anodic peak are found. In presence of cytosine the cathodic peak current of $\mathrm{Cu}$ (II) disappeared significantly or completely while the anodic peak height is reduced appreciably with the negative shifting of peak potential. This observation indicates that the interaction between $\mathrm{Cu}(\mathrm{II})$ and cytosine occurs in BR buffer medium at acidic $\mathrm{pH}$. Among the studied $\mathrm{pH}$ region maximum interaction is found at $\mathrm{pH} 4.08$ when the molar ratio of $\mathrm{Cu}(\mathrm{II}) /$ cytosine is $1: 4$.

\section{Acknowledgement}

Authors are grateful to the Ministry of Science and Technology, Bangladesh for financial support.

\section{References}

1. Berg, J., J. Tymoczko and L. Stryer, 2007. Biochemistry, $6^{\text {th }}$ ed. W.H. Freeman and Company.

2. Kossel, A. and H. Steudel, 1903. Weitere Untersuchungen über das Cytosin, Z Physiol Chem., 38, 49-59.
3. Jaenisch, R. and A. Bird, 2003. Epigenetic regulation of gene expression: how the genome integrates intrinsic and environmental signals, Nat.Genet., 33, 245.

4. Kawasaki, T., K. Suzuki, Y. Hakoda and K. Soai, 2008. Achiral Nucleobase Cytosine Acts as an Origin of Homochirality of Biomolecules in Conjunction with Asymmetric Autocatalysis, Angew. Chem. Int. Ed., 47, $496-$ 499.

5. S. Jasimuddin, 2006. Synthesis, spectral and electrochemical behaviour of cytosinato bridged complexes of ruthenium(II) and platinum(II) with 1-alkyl-2-(arylazo)imidazoles, Trans. Met. Chem., 31, 724-729.

6. Rodriguez, M. and A. J. Bard, 1990. Electrochemical studies of the interaction of metal chelates with DNA. 4. Voltammetric and electrogenerated chemiluminescent studies of the interaction of tris(2,2'-bipyridine)osmium(II) with DNA", Anal. Chem., 62, 2658-2662.

7. Hu, L. Z. Bian, H. Li, S. Han, Y. Yuan, L. Gao and G. Xu, 2009. $\left.\mathrm{Ru}(\mathrm{bpy})_{2} \mathrm{dppz}\right]^{2+}$ Electrochemiluminescence Switch and Its Applications for DNA Interaction Study and Label-free ATP Aptasensor, Anal. Chem., 81, 9807-9811.

8. Kurita, R., K. Arai, K. Nakamoto, D. Kato, and O. Niwa, 2012. Determination of DNA Methylation Using 
Electrochemiluminescence with Surface Accumulable Coreactant, Anal. Chem., 84, 17991803.

9. Quentel F. and C. Madec, 1990. Voltammetric study of the copper-1, 10-phenanthroline complex, Analyt. Chimica Acta. 83, 230.

10. Akhtar, H.M.N., M. M. Jamal, A. A. Shaikh and M. Q. Ehsan, 2008. Cyclic Voltammetric Study of The Interaction of Copper with Glutamic Acid in Solution, J. Saudi Chem. Soc., 12, 177.

11. Polcyn, D. S. and I. Shain, 1996. Multistep Charge Transfers in Stationary Electrode Polarography, Anal. Chem., 38, 370.

12. J. L. Anderson, J. L. and I. Shain, 1976. Cyclic voltammetric studies of the $\mathrm{pH}$ dependence of copper(II) reduction in acidic aqueous nitrate and perchlorate solutions, Anal. Chem., 48, 1274.

13. Miller, R. W. Ph. D. Thesis, The University of Illinois, Urbana III, 1961. 
A. A. Shaikh, Jannatul Firdaws, S. Islam and P. K. Bakshi 
